\title{
Value Relevance of Accounts Receivable Factoring and Its Impact on Financing Strategy under the K-IFRS after COVID-19 from the Perspective of Accounting Big Data
}

\author{
Jung Min Park ${ }^{1}$, Hyoung Yong Lee ${ }^{2, *}$, Sang Hyun Park ${ }^{3}$ and Ingoo Han ${ }^{4}(\mathbb{D}$ \\ 1 College of Business Administration, Kookmin University, 77 Jeongneung-ro, Seongbuk-gu, \\ Seoul 02707, Korea; paspark1@gmail.com \\ 2 School of Business Administration, Hansung University, 116 Samseongyoro-16gil, Seongbuk-gu, \\ Seoul 02864, Korea \\ 3 Hull College of Business, Augusta University, 1120 15th Street, Augusta, GA 30912, USA; \\ sapark@augusta.edu \\ 4 College of Business, Korea Advanced Institute of Science and Technology (KAIST), Seoul 02455, Korea; \\ ighan@kaist.ac.kr \\ * Correspondence: leemit@hansung.ac.kr
}

Received: 31 October 2020; Accepted: 7 December 2020; Published: 9 December 2020

\begin{abstract}
This study investigates whether recognized accounts receivable (AR) factoring is more value relevant than disclosed AR factoring. After the adoption of the Korean International Financial Reporting Standards (K-IFRS), AR factoring is recognized as short-term debt, thus increasing firms' leverage ratio. Using cross-sectional equity valuation regressions, we find that recognized AR factoring is value relevant, unlike disclosed AR factoring. Moreover, the market value of equity and AR factoring are more significantly correlated in highly leveraged firms than in less-leveraged ones. Accounting data are important from the perspective of big data. In the accounting industry as well, professionals started realizing the implications of big data. The COVID-19 pandemic has created a health crisis and wreaked havoc in an already-fragile global economy. Although there is no way to predict exactly what the economic damage from the COVID-19 pandemic will be, there must be widespread agreement that it will have severe financial impact on every company. Global financial markets have suffered dramatic falls due to the pandemic, and highly leveraged companies are in serious need of financing. While diving deeper, sound debt management and debt transparency are critical to ensure debt sustainability. Thus, companies would be willing to use AR factoring in order to overcome this financial status. This study also shows that highly leveraged firms decrease AR factoring after K-IFRS adoption.
\end{abstract}

Keywords: value relevance; accounts receivable factoring; recognition; disclosure; K-IFRS; leverage

\section{Introduction}

As credit sales and receivables increase significantly, companies frequently sell their receivables to financing companies and banks, referred to as factors, for cash. When a company sells accounts receivable (AR) to a factor, the transaction may be treated as: (i) a sale or (ii) borrowing money. In Korea, most companies sell their AR with recourse because factors generally require recourse factoring rather than non-recourse factoring [1]. In AR factoring with recourse, it can be treated as a sale under the Korean Generally Accepted Accounting Principles (K-GAAP), whereas it must be treated as borrowing under the Korean International Financial Reporting Standards (K-IFRS). If AR factoring is treated 
as a sale, then AR is removed from the Statement of Financial Position (SFP) and is disclosed in footnotes. However, if AR factoring is treated as borrowing, then AR is recognized as short-term debt. Korean companies mandatorily adopted the K-IFRS in 2011. Disclosure practices of AR factoring before K-IFRS and its recognition after K-IFRS provide a unique setting for comparing the valuation implications of the two treatments.

Kim and Choi [2] illustrate the changes in the accounting rules pertinent to the transfer of receivables after the adoption of K-IFRS and suggest that these changes caused significant influences on the structure of assets and liabilities. Unlike in our study, they just show practical procedures for the transfer of accounts receivable using two companies' cases. The extant literature provides mixed results about the similarity between recognition and disclosure. Some studies show that disclosed information is similar to recognized information [3-5]. Other studies provide evidence suggesting that investors generally find recognized information more pertinent than disclosed information [6-8].

Throughout the test, we find that the valuation coefficients on recognized AR factoring are more negatively significant, whereas the valuation coefficients on disclosed AR factoring are not significant. The market value of equity and AR factoring are more negatively correlated in highly leveraged firms than in less-leveraged ones. Additional tests show that highly leveraged firms decrease their use of AR factoring as a financing tool after the adoption of the K-IFRS. The results of this study are useful for standard-setters and researchers, and contribute to the growing literature on the difference in the market's reaction to how information is provided. Findings in the study also indicate that the change in the accounting standards can modify the financing strategy.

The integration of big data with advanced technologies like blockchain, artificial intelligence (AI), automation, and machine learning helps create a robust and automated accounting process. According to a recent report from the Institute of Management Accountants, finance and accounting professionals are increasingly implementing big data in their business processes, and the pattern is likely to continue in the future.

Accounting data are starting to emerge as one of the key perspectives of big data. In the accounting industry as well, the professionals have started realizing the implications of big data.

The COVID-19 pandemic resulted in a devastating blow to our global economy. The non-financial crisis, a sharp downturn in business activity, and turmoil in global financial markets caught companies with high debt ratios, bringing us to a defining moment in our world history. As these companies respond to the pandemic, their debt will only increase. These companies are in serious need of financing, and sound debt management and debt transparency are critical to ensure that debt sustainability is finally regained and financial risks are constrained.

The remainder of the paper is structured as follows: Section 2 discusses prior literature. Section 3 presents the hypothesis development and the research design. Section 4 describes the sample selection and data. Section 5 explains the results of the main research models. Section 6 presents additional analyses. Finally, Section 7 summarizes the findings and provides a conclusion.

\section{Literature Review}

One of the crucial issues in accounting research is whether recognition and disclosure are substitutes or not. Thus, many researchers examine the difference between recognition and disclosure. The effects of recognition and disclosure on accounting information should be consistent from the perspective of market efficiency. Consistently with this view, Dhaliwal [3] and Imhoff et al. [4] find that certain footnote information, such as pension and lease obligations, are incorporated into market risk assessments similarly to recognized debt. Bratten, Choudhary, and Schipper [5] find evidence that recognized information and disclosed information are processed similarly when the disclosed information is salient, reliable, and easily processed.

On the contrary, Davis-Friday et al. [6] find evidence that market prices of post-retirement benefit (PRB) liability differ after it is recognized under the Statements of Financial Accounting Standards (SFAS) No. 106. They show that disclosed PRB liability information affects stock prices less than 
recognized PRB liability does, suggesting that the market's impact on disclosed items is less than on recognized items. Similarly, Ahmed et al. [7] investigate the value relevance of banks' recognized and disclosed derivative financial instruments and find that the valuation coefficients of recognized derivatives are significant, unlike those of disclosed derivatives. They also show that disclosed derivatives that are later recognized under SFAS No. 133 are not value relevant, whereas recognized derivatives are.

Researchers also provide several reasons for investors' different reactions toward disclosed and recognized items. Firstly, some studies show that recognized information is more reliable than disclosed information [9]. Other studies suggest that the treatment of disclosed and recognized information varies due to information-processing-related factors [10,11]. Furthermore, due to the lack of knowledge [12] and limited attention to disclosure [11], financial information users may treat disclosed and recognized items differently. Michels [8] finds that investors underreact to disclosed events, which is consistent with investors incurring higher processing costs when using disclosed information. Similarly, experimental studies provide evidence that such financial information users ignore disclosed information, unlike recognized information [13].

Previous literature on financial asset transfers shows that the risk relevance of recognized and disclosed information is similar. Landsman, Peasnell, and Shakespeare [14] examine the equity valuations of assets and liabilities of a special purpose entity and find that the market views these assets and liabilities as belonging to a sponsoring originator. Niu and Richardson [15] show that onand off-balance-sheet debts related to securitization share the same risk relevance in explaining market risk assessments. They also argue that investors consider off-balance-sheet debt when evaluating the value relevance of securitization gain. Although these studies focus on financial firms, the results from Landsman et al. [14] and Niu and Richardson [15] imply that investors interpret securitizations as a secured borrowing, as credit analysts often do. Moody's, a credit rating company, states, "To date, we have observed very few examples of meaningful risk transference through securitization" [16]. It further describes securitization as an on-balance-sheet secured financing when it fails to transfer meaningful risk.

Similarly to securitization, AR factoring is one of the financial asset transfers. Under K-GAAP, financial asset transfers can be recorded either as a sale or a secured borrowing depending on the surrender of control. On the contrary, financial asset transfers must evaluate the transfer of risks and rewards and the surrender of control under the K-IFRS. Therefore, the derecognition of financial asset transfers under the K-IFRS is more complicated than that under the K-GAAP. AR factoring can be classified into two categories, with recourse and without recourse. In Korea, most companies factor AR with recourse. AR factoring with recourse can be derecognized under the K-GAAP considering the practice and corporate burden if transferors surrender control over AR. However, AR factoring with recourse has to be recorded as a secured borrowing because a transferor has to repay the amount of AR when it becomes uncollectable, which means that the transferor still bears all the risks embedded in AR. Thus, firms have to recognize AR factoring amounts as assets and liabilities after they factor AR after K-IFRS adoption. Because of this, firms have to bear increases in leverage ratio and debt-to-equity $(\mathrm{D} / \mathrm{E})$ ratio.

\section{Hypothesis Development and Research Design}

\subsection{Hypothesis Development}

Accounting principle changes regarding financial asset transfers result in leverage ratio differences. After K-IFRS adoption, transferor companies' leverage ratios increased, although their economic realities were unchanged. If so, do presentation format changes affect investors' perception? Maines and McDaniel [13] find that nonprofessional investors' judgments of corporate and management performance reflect the volatility of comprehensive income only when presented in the statement of comprehensive income. Ahmed et al. [7] show that the valuation coefficients on recognized derivatives 
are significant, whereas the valuation coefficients on disclosed derivatives are not significant after SFAS 133. Müller, Riedl, and Sellhorn [17] find a lower association between equity prices and disclosed relative to recognized investment property fair values under the IFRS. Davis-Friday et al. [9] find evidence that is consistent with the market treating disclosed PRB liabilities as less reliable than recognized PRB liabilities and pension liabilities under SFAS No. 106. Additionally, prior studies show that an increase in leverage ratio can result in a lower stock price [18] and drops in the market value of equity [19], all else being equal. Dimitrov and Jain [20] also find that changes in financial leverage are negatively associated with risk-adjusted stock returns. Based on the theoretical models of Myers [21] and Myers and Majluf [22], they argue that changes in financial leverage are value relevant beyond earning-related variables. Therefore, we expect that recognized AR factoring increases leverage ratios, and then they are value relevant, unlike disclosed AR factoring. Thus, we propose our first hypothesis as follows:

Hypothesis 1 (H1). The market perceives recognized AR factoring as more negative than previously disclosed AR factoring.

Investors' assessment of leverage ratio increases differs depending on firms' pre-existing conditions. According to Cai and Zhang [18], there is a significant and negative effect of a firm's change in leverage ratio on its stock prices. They find that the negative effect is more substantial for firms that have higher leverage ratios and a higher likelihood of default and that face more severe financial constraints. Based on their findings, investors may react to AR factoring more negatively for firms with high leverage ratios. Because recognized AR factoring increases total assets and total liabilities simultaneously, firms' leverage ratio and D/E ratio increase. This becomes a burden on highly leveraged firms. Excessive leverage ratios can drive firms into a corner; for example, debt covenant violations and additional funding difficulties. Thus, we propose the following hypothesis:

Hypothesis 2 (H2). The negative relationship between recognized AR factoring and a firm's equity value is more pronounced for highly leveraged firms than less-leveraged firms.

Evidence from academic research suggests that firms are reluctant to report higher debt. Imhoff and Thomas [23] demonstrate that in response to SFAS No. 13, firms restructure their leases in order to avoid recording debt on the balance sheet. Engel, Erickson, and Maydew [24] identify certain firms that incur significant transaction costs in order to repackage straight debt into a preferred stock that has tax-deductible dividend payments (similar to debt) but that is classified as equity on the firm's balance sheet based on GAAP. That is, due to their aversion to leverage, firms structure contracts to avoid obligations from recognizing the debt. Furthermore, GAAP changes can affect the economic agents' actions. Bens and Monahan [25] find that the Financial Accounting Standards Board Interpretation No. 46 (FIN 46) appears to have raised the cost of sponsoring asset-backed commercial paper (ABCP) conduits. As a result, North American banks responded by sponsoring less $\mathrm{ABCP}$ and by purchasing consolidation services from expected loss note investors. In this context, a firm may not factor AR due to the increase in leverage ratio caused by AR factoring recognition. When a highly leveraged firm factors AR, its leverage ratio increases; thus, investors would suspect whether the firm is under financial distress. Therefore, highly leveraged firms have incentives to reduce AR factoring under the K-IFRS. This leads to the following hypothesis:

Hypothesis 3 (H3). When a highly leveraged firm needs financial capital, it is less likely to factor AR under the K-IFRS than under the K-GAAP. 


\subsection{Research Design}

Using a sample of Korean Stock Exchange (KSE)—and Korea Securities Dealers Automated Quotations (KOSDAQ) - listed firms for the period 2004-2012, we examine whether the value relevance of AR factoring differs before and after K-IFRS adoption. Furthermore, we test whether this change is more evident among highly leveraged firms. Market participants are more concerned about short-term debts when a firm's financial risk is high. Thus, we expect that book-value relevance is higher for highly leveraged firms when AR factoring is recognized compared with less-leveraged ones. We also test whether the financing strategy using AR factoring changes after K-IFRS adoption.

Value relevance research examines the relationship between accounting amounts and the market value of equity. Valuation models could be price models, return models, differenced-price models, or deflated-price models. Kothari and Zimmerman [26] show that although a price model is more likely to have econometric problems, such as omitted variables, when compared to a return model, the price model is economically better specified, and the slope coefficient estimates are unbiased or less biased. Barth, Beaver, and Landsman [27] suggest that a price model (level model) should be used when researchers intend to investigate what is reflected in firm value. Value relevance studies that investigate differences between recognized and disclosed information use price models that examine the ability of assets and liabilities to explain market equity value $[6,14,28]$.

The study aims to determine whether market responses to AR factoring differ after K-IFRS adoption. This research is related to studies regarding disclosure and recognition $[6,7,28]$. Thus, we address our research question by estimating a cross-sectional valuation model similar to those in prior literature [14,28]. The estimating equations are based on the models of Ohlson [29] and Feltham and Ohlson [30]. All regressions are estimated using per-share amounts. We begin by estimating a benchmark regression, given by Equation (1), as follows:

$$
M V E_{i t}=\beta_{0}+\beta_{1} N I_{i t}+\beta_{2} B V A_{i t}+\beta_{3} B V L_{i t}+\varepsilon_{i t}
$$

where $M V E$ is the equity market value, $N I$ is the net income, $B V A$ and $B V L$ are the book values of total assets and liabilities, all measured on a per-share basis. $B V A$ and $B V L$ are measured the fiscal year-end, $M V E$ is measured three months after the fiscal year-end, and the $i$ and $t$ subscripts denote the firm and year, respectively.

This study examines whether the market's reaction to AR factoring differs before and after K-IFRS adoption. Thus, the new estimating equation includes AR factoring before and after K-IFRS adoption. It can be described as follows:

$$
\begin{array}{r}
M V E_{i t}=\beta_{0}+\beta_{1} I F R S+\beta_{2} N I_{i t}+\beta_{3} I F R S \times N I_{i t}+\beta_{4} B V A_{i t}+\beta_{5} I F R S \times B V A_{i t}+\beta_{6} B V L_{i t}+\beta_{7} I F R S \times \\
B V L_{i t}+\beta_{8} A R F_{i t}+\beta_{9} I F R S \times A R F_{i t}+\beta_{10} G R W_{i t}+\beta_{11} I F R S \times G R W_{i t}+\beta_{12} R D_{i t}+\beta_{13} I F R S \times R D_{i t}+\varepsilon_{i t},
\end{array}
$$

where all variables are as defined in the Appendix A for firm $i$ and year $t$. ARF is the amount of AR factoring. Hypothesis 1 predicts that the coefficient of IFRS $\times A R F, \beta_{9}$, is expected to be negative because recognized AR factoring increases the leverage ratio after K-IFRS adoption. In addition, the significant value of the coefficient of $A R F, \beta_{8}$, indicates the value relevance of disclosed AR factoring. We include research and development expenses $(R D)$ and growth opportunity $(G R W)$ as control variables in Equation (2). Consistently with prior research [28,31,32], we include $R D$ to reduce the service cost anomaly and $G R W$ to control growth opportunities not reflected in the financial statement.

Hypothesis 2 predicts that AR factoring recognition impacts highly leveraged firms' stock prices compared with less-leveraged ones. To this hypothesis, we estimate Equation (2) for a subsample of firms classified into two groups based on the leverage ratio. Empirically, Hypothesis 2 implies that the coefficient of IFRS $\times A R F, \beta_{9}$, is expected to be more negative for the subsample of highly leveraged firms than that for the subsample of less-leveraged firms.

If firms are concerned about increasing their leverage ratios due to AR factoring, they will avoid it as a financing tool. We begin our analysis with univariate comparisons of the changes in AR factoring 
and the changes in AR factoring divided by total assets before and after K-IFRS adoption using a difference-in-differences design. Then, we investigate whether highly leveraged firms decrease AR factoring after K-IFRS adoption using the following model:

$$
A R F_{-} F N=\beta_{0}+\beta_{1} I F R S+\beta_{2} F N_{i t}+\beta_{3} I F R S \times F N_{i t}+\beta_{4} S I Z E_{i t}+\beta_{5} I F R S \times S I Z E_{i t}+\varepsilon_{i t},
$$

where all variables for firm $i$ and year $t$ are as defined in the Appendix $A$, and $\beta_{2}$ and $\beta_{3}$ are the coefficients of interest in Equation (3). When a highly leveraged firm needs cash, AR factoring is favorable under the K-GAAP. Because a firm can finance with low costs or transfer credit risks to third parties without increasing the leverage ratio, $\beta_{2}$ is expected to be significantly positive. However, under the K-IFRS, AR factoring is generally considered short-term debt because of the rigorous standard of financial asset transfer. Thus, $\beta_{3}$ is expected to be significantly negative.

\section{Sample Selection and Descriptive Statistics}

The study sample consists of KSE- and KOSDAQ-listed firms that factored AR continuously from 2004 to 2012. We include only firms that factored AR in pre- and post-K-IFRS periods to allow a comparison of the same set of firms between the periods. However, we also conduct an additional analysis of companies that factored AR at least once during the sample periods and find similar results. Post-K-IFRS periods include 2011 and 2012. Thus, this study provides early evidence of the effect of AR factoring recognition. We used the Financial Supervisory Service's Data Analysis, Retrieval, and Transfer System to search footnote information in audit reports related to AR factoring and hand-collect AR factoring data. We also used the FnGuide data system to obtain financial information and stock prices. We exclude financial firms because they possess loan obligations rather than accounts receivable, and they systematically operate differently from other firms. We also choose firms with positive equity values. To eliminate statistical problems associated with calendar time alignment, the sample includes only firms with 31 December as the fiscal year end. The final sample includes 1179 firm-year observations of 131 unique firms. Table 1 shows the samples' selection procedure. Table 2 presents the industry distribution of the sample. The firms are distributed in various industries, which suggests that AR factoring is a common financing tool.

Table 1. Sample selection procedure.

\begin{tabular}{cc}
\hline & Firm-Years \\
\hline KSE- and KOSDAQ-listed firms from 2004 to 2012 & 15,462 \\
Firms with early adoption of K-IFRS & $(621)$ \\
Observations of firms with fiscal year-end other than December 31 & $(567)$ \\
Observations of firms with negative equity values & $(718)$ \\
Observations without valid accounting and stock price data & $(2040)$ \\
Observations of firms without AR factoring & $(8012)$ \\
Observations of firms that factor AR less frequently & $(1977)$ \\
Firms that factor AR annually & 1179 \\
\hline
\end{tabular}

Panel A of Table 3 shows the descriptive statistics of the main variables of the study. AR factoring averages 70 million USD, which accounts for $7.0 \%, 26.2 \%$, and $13.5 \%$ of assets, AR, and total liabilities, respectively. As expected, the leverage ratio (total liabilities/total assets) and debt-to-equity (D/E) ratio have increased by $2.4 \%$ and $14.6 \%$, respectively, after the K-IFRS adoption. The data also show that the increase in the leverage ratio (and $\mathrm{D} / \mathrm{E}$ ratio) due to $\mathrm{AR}$ factoring recognition is considerably large for some firms. 
Table 2. Sample composition by industry.

\begin{tabular}{|c|c|c|}
\hline Industry Name * & No. of Firms & Percent \\
\hline IT Service & 1 & 0.76 \\
\hline Construction & 4 & 3.05 \\
\hline Construction materials & 6 & 4.58 \\
\hline Metal and mineral & 15 & 11.45 \\
\hline Machinery & 13 & 9.92 \\
\hline Consumer durables & 1 & 0.76 \\
\hline Display devices and components & 2 & 1.53 \\
\hline Trade & 4 & 3.05 \\
\hline Security equipment & 1 & 0.76 \\
\hline Complex industry & 3 & 2.29 \\
\hline Commercial service & 1 & 0.76 \\
\hline Textile and clothing & 8 & 6.11 \\
\hline Groceries & 4 & 3.05 \\
\hline Energy facility and service & 1 & 0.76 \\
\hline Transportation infrastructure & 1 & 0.76 \\
\hline Overland transportation & 4 & 3.05 \\
\hline Beverage & 1 & 0.76 \\
\hline Medical devices and service & 1 & 0.76 \\
\hline Automobile & 2 & 1.53 \\
\hline Automobile components & 18 & 13.74 \\
\hline Electrical equipment & 5 & 3.82 \\
\hline Electronic equipment & 3 & 2.29 \\
\hline Pharmaceutical & 14 & 10.69 \\
\hline Paper and timber & 4 & 3.05 \\
\hline Computer and peripherals & 1 & 0.76 \\
\hline Communication equipment & 1 & 0.76 \\
\hline Chemistry & 12 & 9.16 \\
\hline Total & 131 & 100.00 \\
\hline
\end{tabular}

Panel B of Table 3 shows the mean values of the main variables related to K-GAAP and K-IFRS. $A R F$ has no differences between the two periods per se. However, ARF/BVA is 0.089 and 0.058 under $\mathrm{K}-\mathrm{GAAP}$ and K-IFRS, respectively. Furthermore, $A R F / M V E$ is 0.26 and 0.16 under K-GAAP and K-IFRS, respectively. The difference in variables (ARF/BVA and ARF/MVE) between the two standards is significant at the $1 \%$ level, which suggests that the composition of AR factoring changes significantly from one standard to another.

Panel $\mathrm{C}$ of Table 3 reports the correlation coefficients of the sample using per-share amounts. Spearman (Pearson) correlations are shown above (below) the diagonal. MVE is positively correlated with $B V L$ and $A R F$, suggesting the existence of the scale effect. Davis-Friday et al. [6] and Yu [28] document a similar result, where the market value is positively correlated with liability variables. This is because of the failure to control for the other variables, especially $B V A$, when calculating the individual relations with $M V E$.

Table 3. Various descriptive statistics.

\begin{tabular}{cccccc}
\hline \multicolumn{7}{c}{ Panel A: Descriptive statistics } \\
\hline Variable & Mean & Std. Dev. & Minimum & Median & Maximum \\
\hline MVE & $714,942,383$ & $3,318,708,183$ & $3,914,644$ & $54,556,437$ & $47,419,849,585$ \\
NI & $58,766,238$ & $322,493,884$ & $-220,936,851$ & $3,465,884$ & $4,872,265,647$ \\
BVA & $1,012,447,138$ & $3,695,387,447$ & $11,674,258$ & $119,974,345$ & $48,357,170,575$ \\
BVL & $479,943,311$ & $1,553,874,802$ & 771,807 & $57,593,394$ & $14,486,944,953$ \\
ARF & $69,527,537$ & $285,025,413$ & 16,984 & $7,044,425$ & $3,368,940,444$ \\
MVE/CSO & 18.84 & 32.70 & 0.14 & 7.03 & 327.50 \\
NI/CSO & 1.46 & 3.90 & -32.56 & 0.42 & 43.95 \\
BVA/CSO & 41.09 & 69.85 & 0.41 & 16.87 & 803.97 \\
BVL/CSO & 19.07 & 28.50 & 0.11 & 7.66 & 271.53 \\
ARF/CSO & 2.50 & 4.16 & 0.00 & 0.78 & 53.14 \\
\hline
\end{tabular}


Table 3. Cont.

\begin{tabular}{|c|c|c|c|c|c|}
\hline \multicolumn{6}{|c|}{ Panel B: Means of the main variables for K-GAAP and K-IFRS } \\
\hline Variable & K-GAAP (2004-2010) & \multicolumn{2}{|c|}{ K-IFRS (2011-2012) } & \multicolumn{2}{|c|}{$\begin{array}{c}\text { Differences } \\
\text { (K-IFRS-K-GAAP) }\end{array}$} \\
\hline MVE & $580,712,928$ & \multicolumn{2}{|c|}{$1,184,752,905$} & \multicolumn{2}{|c|}{$604,039,976$} \\
\hline NI & $50,452,467$ & \multicolumn{2}{|c|}{$87,865,049$} & \multicolumn{2}{|c|}{$37,412,582$} \\
\hline BVA & $885,924,876$ & \multicolumn{2}{|c|}{$1,455,285,578$} & \multicolumn{2}{|c|}{$569,360,702$} \\
\hline BVL & $435,435,284$ & \multicolumn{2}{|c|}{$635,726,391$} & \multicolumn{2}{|c|}{$200,291,107$} \\
\hline $\mathrm{ARF}$ & $69,440,972$ & \multicolumn{2}{|c|}{$69,831,236$} & \multicolumn{2}{|c|}{390,264} \\
\hline $\mathrm{MVE} / \mathrm{CSO}$ & 17.49 & \multicolumn{2}{|c|}{23.54} & \multicolumn{2}{|c|}{$6.04 * *$} \\
\hline $\mathrm{NI} / \mathrm{CSO}$ & 1.39 & \multicolumn{2}{|c|}{1.70} & \multicolumn{2}{|c|}{0.31} \\
\hline $\mathrm{BVA} / \mathrm{CSO}$ & 38.97 & \multicolumn{2}{|c|}{48.51} & \multicolumn{2}{|c|}{9.53} \\
\hline $\mathrm{BVL} / \mathrm{CSO}$ & 18.28 & \multicolumn{2}{|c|}{21.83} & \multicolumn{2}{|c|}{3.55} \\
\hline ARF/CSO & 2.57 & \multicolumn{2}{|c|}{2.25} & \multicolumn{2}{|c|}{-0.32} \\
\hline ARF/BVA & 0.089 & \multicolumn{2}{|c|}{0.058} & & $* * *$ \\
\hline ARF/MVE & 0.26 & & & & $* * *$ \\
\hline No. of Obs. & 917 & & & & \\
\hline & Panel C: & Pearson & nan correlat & & \\
\hline & MVE/CSO & $\mathrm{NI} / \mathrm{CSO}$ & BVA/CSO & BVL/CSO & ARF/CSO \\
\hline MVE/CSO & & $0.73^{* * *}$ & $0.85^{* * *}$ & $0.75^{* * *}$ & $0.61 * * *$ \\
\hline NI/CSO & $0.73^{* * *}$ & & $0.62^{* * *}$ & $0.50^{* * *}$ & $0.47^{* * *}$ \\
\hline BVA/CSO & $0.67^{* * *}$ & $0.53^{* * *}$ & & $0.95^{* * *}$ & $0.72^{* * *}$ \\
\hline BVL/CSO & $0.49^{* * *}$ & $0.31^{* * *}$ & $0.92 * * *$ & & $0.72^{* * *}$ \\
\hline ARF/CSO & $0.37^{* * *}$ & $0.32 * * *$ & $0.65^{* * *}$ & $0.68^{* * *}$ & \\
\hline
\end{tabular}

Notes: ${ }^{* *}$, and ${ }^{* * *}$ denote the significance of coefficients at the $10 \%, 5 \%$, and $1 \%$ level, respectively, using a two-tailed test. Please see the Appendix A for variable definitions. MVE, NI, BVA, BVL, and ARF in panels A and B are in USD (the exchange rate is $1082.34 \mathrm{KRW} / \mathrm{USD}$ ). Panel C reports the correlation coefficients of the main variables. The upper and lower diagonals show the Spearman and Pearson correlations, respectively.

\section{Test Results}

\subsection{Value Relevance of AR Factoring}

Table 4 presents the results of the value relevance test. The marginally significant coefficient of $A R F(\mathrm{t}$-statistic $=-1.82$ ) suggests that investors do pay less attention to off-balance-sheet contingent liabilities related to AR factoring disclosed in the footnotes. However, the coefficient of IFRS *ARF is significantly negative $(\mathrm{t}$-statistic $=-3.58)$, suggesting that the K-IFRS increases the value relevance of previously disclosed off-balance-sheet AR factoring.

The coefficients of other variables generally exhibit the expected signs. The coefficients of $N I$ (coefficient $=1.894$ and $\mathrm{t}$-statistic $=7.89)$ and $B V A($ coefficient $=0.407$ and $\mathrm{t}$-statistic $=9.81)$ are significantly positive, whereas that of $B V L$ is significantly negative (coefficient $=-0.379$ and $\mathrm{t}$-statistic $=-4.76$ ). As control variables, $G R W$ is not significant and $R D$ is positively significant (coefficient $=8.261$ and $\mathrm{t}$-statistic $=7.25$ ). The coefficients on the interaction terms with IFRS are questionable because the effect of K-IFRS adoption on assets, liabilities, net income, growth, and research and development $(R \& D)$ may be mixed.

Table 5 presents the results of the value relevance tests for the subsample. The coefficients of $A R F$ in both subsamples (in the highly leveraged sample firms, coefficient $=-0.316$ and t-statistic $=-1.23$; less-leveraged sample firms, coefficient $=-0.770$ and $t$-statistics $=-1.7$ ) are not significant and marginally significant. This suggests that investors ignore off-balance-sheet liabilities related to AR factoring when they are only disclosed in the footnotes. However, the coefficient of IFRS $\times A R F$ (coefficient $=-0.646$ and $\mathrm{t}$-statistic $=-2.59$ ) in the highly leveraged sample firms is significantly negative, whereas that of IFRS $\times A R F$ (coefficient $=-0.156$ and $t$-statistic $=-0.22$ ) in the less-leveraged sample firms is not significant, implying that the value relevance of recognized AR factoring is more evident in highly leveraged firms. 
Table 4. Value relevance test of recognized versus disclosed AR factoring.

\begin{tabular}{cccc}
\hline Variable & Predicted Sign & Coefficient & (t-Statistics) \\
\hline Intercept & $?$ & 2.983 & $(0.85)$ \\
IFRS & $?$ & -1.656 & $(-1.16)$ \\
NI & + & 1.894 & $(7.89)^{* * *}$ \\
IFRS * NI & $?$ & 2.109 & $(5.81)^{* * *}$ \\
BVA & + & 0.407 & $(9.81)^{* * *}$ \\
IFRS * BVA & $?$ & -0.134 & $(-3.67)^{* * *}$ \\
BVL & - & -0.379 & $(-4.76)^{* * *}$ \\
IFRS * BVL & $?$ & 0.166 & $(2.35)^{* *}$ \\
ARF & - & -0.381 & $(-1.82)^{*}$ \\
IFRS* ARF & - & -0.781 & $(-3.58)^{* * *}$ \\
GRW & + & -1.202 & $(-0.69)$ \\
IFRS* GRW & $?$ & 1.261 & $(0.26)$ \\
RD & + & 8.261 & $(7.25)^{* * *}$ \\
IFRS * RD & $?$ & 1.120 & $(1.22)$ \\
Fixed Firm & & \multicolumn{3}{c}{ Yes } \\
and Year & & \multicolumn{3}{c}{0.892} \\
Effects & & \multicolumn{3}{c}{1.179} \\
R & & & \\
No. of & & &
\end{tabular}

Notes: ${ }^{*}, * *$, and $* * *$ denote the significance of coefficients at the $10 \%, 5 \%$, and $1 \%$ level, respectively, using a two-tailed test. All the variables are winsorized at the top and bottom $1 \%$. Please see the Appendix A for variable definitions. All variables, except for IFRS and GRW, are measured on a per-share basis by deflating by common shares outstanding three months after year-end.

Table 5. Value relevance tests of AR factoring using the subsample.

\begin{tabular}{|c|c|c|c|c|c|}
\hline \multirow{2}{*}{ Variable } & \multirow{2}{*}{ Predicted Sign } & \multicolumn{2}{|c|}{ Highly Leveraged Firms } & \multicolumn{2}{|c|}{ Less-Leveraged Firms } \\
\hline & & Coefficient & (t-Statistics) & Coefficient & (t-Statistics) \\
\hline Intercept & $?$ & 1.137 & $(0.12)$ & 4.799 & $(1.08)$ \\
\hline IFRS & $?$ & 0.845 & $(0.52)$ & -4.571 & $(-1.56)$ \\
\hline NI & + & 1.155 & $(3.53)^{* * *}$ & 2.249 & $(5.38) * * *$ \\
\hline IFRS * NI & $?$ & 1.356 & $(1.95) *$ & 1.939 & $(2.64) * * *$ \\
\hline BVA & + & 0.518 & $(8.63)^{* * *}$ & 0.267 & $(2.94) * * *$ \\
\hline IFRS * BVA & $?$ & -0.477 & $(-5.14) * * *$ & -0.179 & $(-2.94) * * *$ \\
\hline BVL & - & -0.533 & $(-4.53) * * *$ & 0.019 & $(0.1)$ \\
\hline IFRS * BVL & $?$ & 0.703 & $(4.7)^{* * *}$ & 0.352 & $(2.13)^{* *}$ \\
\hline $\mathrm{ARF}$ & - & -0.316 & $(-1.23)$ & -0.770 & $(-1.7) *$ \\
\hline IFRS * ARF & - & -0.646 & $(-2.59)^{* * *}$ & -0.156 & $(-0.22)$ \\
\hline GRW & + & -1.571 & $(-0.78)$ & -2.653 & $(-0.71)$ \\
\hline IFRS * GRW & $?$ & 6.464 & $(1.11)$ & -2.384 & $(-0.27)$ \\
\hline $\mathrm{RD}$ & + & 9.437 & $(6.84)^{* * *}$ & 5.859 & $(2.7)^{* * *}$ \\
\hline IFRS * RD & $?$ & -0.853 & $(-0.73)$ & 2.914 & $(1.75)$ \\
\hline \multirow{2}{*}{\multicolumn{2}{|c|}{$\begin{array}{l}\text { Fixed firm and year Effects } \\
\qquad R^{2}\end{array}$}} & \multicolumn{2}{|c|}{ Yes } & \multicolumn{2}{|c|}{ Yes } \\
\hline & & \multicolumn{2}{|c|}{0.846} & \multicolumn{2}{|c|}{0.812} \\
\hline \multicolumn{2}{|c|}{ No. of observations } & \multicolumn{2}{|c|}{763} & \multicolumn{2}{|c|}{416} \\
\hline
\end{tabular}

Notes: ${ }^{*}, * *$, and ${ }^{* * *}$ denote the significance of coefficients at the $10 \%, 5 \%$, and $1 \%$ level, respectively, using a two-tailed test. All the variables are winsorized at the top and bottom 1\%. Please see the Appendix A for variable definitions. All variables, except for IFRS and GRW, are measured on a per-share basis by deflating by common shares outstanding three months after year-end.

\subsection{The Change in Financing Strategy Using AR Factoring}

Table 6 reports the mean values of the changes in AR factoring and AR factoring ratios for the fiscal years under the K-GAAP and K-IFRS. In the less-leveraged firms, the means of the changes in AR factoring in the years under the K-GAAP and K-IFRS are 2.6 million and -5.0 million USD, respectively. This difference between the changes in AR factoring under the K-GAAP and K-IFRS is not significant (t-statistic $=1.06$ ). The changes in AR factoring ratio in the years under K-GAAP and K-IFRS are $-0.534 \%$ and $-1.24 \%$, respectively. The difference in the changes in AR factoring ratio between the two periods is marginally significant $(\mathrm{t}$-statistic $=1.95)$. 
Table 6. Tests of the change in financing strategy using AR factoring.

\begin{tabular}{|c|c|c|c|}
\hline & K-GAAP & K-IFRS & Tests of Differences \\
\hline & Mean & Mean & t-Statistic \\
\hline \multicolumn{4}{|l|}{ Highly leveraged } \\
\hline$\triangle \mathrm{ARF}$ & $5,031,713$ & $-3,148,596$ & $2.51^{* *}$ \\
\hline$\Delta(\mathrm{ARF} / \mathrm{ASSET})$ & $-0.051 \%$ & $-0.948 \%$ & $3.37 * * *$ \\
\hline \multicolumn{4}{|c|}{ Less-leveraged Firm } \\
\hline$\triangle \mathrm{ARF}$ & $2,672,359$ & $-5,010,522$ & 1.06 \\
\hline$\Delta(\mathrm{ARF} / \mathrm{ASSET})$ & $-0.534 \%$ & $-1.24 \%$ & $1.95 *$ \\
\hline
\end{tabular}

Notes: $*, * *$, and ${ }^{* * *}$ denote the significance of coefficients at the $10 \%, 5 \%$, and $1 \%$ level, respectively, using a two-tailed test. All the variables are winsorized at the top and bottom $1 \% . \triangle \mathrm{ARF}$ is in USD (the exchange rate is 1082.34 KRW/USD). Please see the Appendix A for variable definitions.

Conversely, in the highly leveraged firms, the means of the changes in AR factoring in the years under the K-GAAP and K-IFRS are 5.0 million and -3.1 million USD, respectively. The difference in the changes in AR factoring between the K-GAAP and K-IFRS is significant at the $5 \%$ level (t-statistic $=2.51$ ). In addition, the changes in AR factoring ratio in the years under the K-GAAP and K-IFRS are $-0.051 \%$ and $-0.948 \%$, respectively. The difference in the change in the AR factoring ratios between the two periods is significant at the $1 \%$ level ( $\mathrm{t}$-statistic $=3.37$ ). The results show that firms' financing strategy using AR factoring is reduced after the K-IFRS adoption, particularly in highly leveraged firms.

Table 7 presents the test results of the change in AR financing by motivation. Prior literature reports that low-credit-rated firms and small firms are more likely to factor AR [33]. Securing cash from assets is one of the motivations of AR factoring. Thus, we examine whether firms' AR financing strategy is affected by K-IFRS adoption using Equation (3). In the highly leveraged sample firms, the coefficient of IFRS is significantly negative, suggesting that highly leveraged firms rapidly decrease AR factoring after the K-IFRS adoption. The coefficient of $F N$ is significantly positive, whereas that of IFRS $\times F N$ is significantly negative. This finding suggests that firms with sufficient cash decrease AR factoring after K-IFRS adoption. In the less-leveraged sample firms, the coefficients of $F N$ and IFRS $\times F N$ are not significant and marginally significant, suggesting that less-leveraged firms do not change the use of AR factoring strategy much.

Table 7. Test of the change in AR financing by motivation.

\begin{tabular}{cccccc}
\hline \multirow{2}{*}{ Variable } & \multirow{2}{*}{ Predicted Sign } & \multicolumn{2}{c}{ Highly Leveraged Firms } & \multicolumn{2}{c}{ Less-Leveraged Firms } \\
\cline { 3 - 6 } & & Coefficient & (t-Statistics) & Coefficient & (t-Statistics) \\
\hline Intercept & $?$ & 26.140 & $(6.93)^{* * *}$ & 3.131 & $(0.8)$ \\
IFRS & - & -27.175 & $(-3.33)^{* * *}$ & -6.809 & $(-0.85)$ \\
FN & + & 9.090 & $(2.92)^{* * *}$ & 3.293 & $(0.83)$ \\
IFRS * FN & - & -18.062 & $(-2.56)^{* *}$ & -16.686 & $(-1.88)^{*}$ \\
SIZE & - & -0.946 & $(-4.78)^{* * *}$ & 0.181 & $(0.88)$ \\
IFRS * SIZE & $?$ & 1.284 & $(3.04)^{* * *}$ & 0.185 & $(0.45)$ \\
R $^{2}$ & & \multicolumn{2}{c}{0.057} & & 0.051 \\
No. of Observations & \multicolumn{2}{c}{763} & & 416 \\
\hline
\end{tabular}

Notes: ${ }^{*}, * *$, and ${ }^{* * *}$ denote the significance of coefficients at the $10 \%, 5 \%$, and $1 \%$ level, respectively, using a two-tailed test. All the variables are winsorized at the top and bottom $1 \%$. Please see the Appendix A for variable definitions.

Moreover, the coefficient of SIZE is significantly negative in the highly leveraged sample firms, whereas the coefficient of IFRS $\times$ SIZE is significantly positive, suggesting that small firms are more likely to use AR factoring under the K-GAAP compared with K-IFRS. In the less-leveraged sample firms, the coefficients of SIZE and IFRS $\times$ SIZE are not significant. 


\section{Additional Analyses}

\subsection{Robustness Tests}

Following Davis-Friday et al. [6] and Ahmed et al. [7], this study uses the number of shares outstanding as a deflator. However, prior literature argues that the results of value relevance research may be sensitive to the choice of deflators [34]. Thus, we consider sales volume and book value of equity as alternative deflators in level models used in previous literature [28].

Table 8 presents the test results of the value relevance of AR factoring when other deflators are used. Panel A of Table 8 presents the results of value relevance tests using sales volume as a deflator. While the coefficient of ARF (coefficient $=1.278$ and t-statistic $=3.32$ ) is significantly positive, that of IFRS * ARF (coefficient $=-0.975$ and $\mathrm{t}$-statistic $=-2.61$ ) is significantly negative in the highly leveraged sample firms. This suggests that $A R F$ has negative value relevance after K-IFRS adoption. In the less-leveraged sample firms, the coefficients of $A R F$ and IFRS $\times A R F$ are not significant. These results are consistent with the role of AR factoring in decreasing credit risk exposure $[33,35,36]$.

Table 8. Value relevance tests of AR factoring using other deflators.

\begin{tabular}{|c|c|c|c|c|c|}
\hline \multicolumn{6}{|c|}{ Panel A: Sales Deflator } \\
\hline \multirow{2}{*}{ Variable } & \multirow{2}{*}{ Predicted Sign } & \multicolumn{2}{|c|}{ Highly Leveraged Firms } & \multicolumn{2}{|c|}{ Less-Leveraged Firms } \\
\hline & & Coefficient & (t-Statistics) & Coefficient & (t-Statistics) \\
\hline Intercept & $?$ & -0.340 & $(-0.97)$ & -0.097 & $(-0.44)$ \\
\hline IFRS & $?$ & -0.012 & $(-0.13)$ & 0.126 & $(0.7)$ \\
\hline NI & + & -0.014 & $(-0.06)$ & 1.575 & $(3.69)^{* * *}$ \\
\hline IFRS * NI & $?$ & -1.095 & $(-2.3)^{* *}$ & -0.522 & $(-0.79)$ \\
\hline BVA & + & 0.978 & $(7.42)^{* * *}$ & 0.731 & $(5.33)^{* * *}$ \\
\hline IFRS * BVA & $?$ & 0.021 & $(0.12)$ & -0.016 & $(-0.11)$ \\
\hline BVL & - & -1.061 & $(-5.43)^{* * *}$ & -0.843 & $(-2.3) * *$ \\
\hline IFRS * BVL & $?$ & 0.005 & $(0.02)$ & -0.124 & $(-0.28)$ \\
\hline ARF & - & 1.278 & $(3.32)^{* * *}$ & 0.253 & $(0.32)$ \\
\hline IFRS * ARF & - & -0.975 & $(-2.61)^{* * *}$ & 0.914 & $(0.63)$ \\
\hline GRW & + & -0.108 & $(-1.34)$ & -0.070 & $(-0.52)$ \\
\hline IFRS * GRW & $?$ & 0.667 & $(2.93) * * *$ & 0.327 & (1) \\
\hline $\mathrm{RD}$ & + & -0.363 & $(-0.15)$ & 2.093 & $(0.7)$ \\
\hline IFRS * RD & $?$ & 1.497 & $(0.81)$ & -0.103 & $(-0.03)$ \\
\hline \multirow{2}{*}{\multicolumn{2}{|c|}{$\begin{array}{l}\text { Fixed Firm and Year Effects } \\
\qquad R^{2}\end{array}$}} & Yes & & Yes & \\
\hline & & 0.693 & & 0.763 & \\
\hline \multicolumn{2}{|c|}{ No. of Observations } & 763 & & 416 & \\
\hline \multicolumn{6}{|c|}{ Panel B: Book Value of Equity Deflator } \\
\hline \multirow{2}{*}{ Variable } & \multirow{2}{*}{ Predicted Sign } & \multicolumn{2}{|c|}{ Highly Leveraged Firms } & \multicolumn{2}{|c|}{ Less-Leveraged Firms } \\
\hline & & Coefficient & (t-statistics) & Coefficient & (t-statistics) \\
\hline Intercept & $?$ & -0.004 & $(-0.01)$ & 0.298 & $(0.85)$ \\
\hline IFRS & $?$ & 0.135 & $(0.63)$ & -0.029 & $(-0.13)$ \\
\hline NI & + & 0.597 & $(3.42)^{* * *}$ & 2.086 & $(3.97)^{* * *}$ \\
\hline IFRS * NI & $?$ & -0.711 & $(-2.16) * *$ & 1.634 & (1.6) \\
\hline BVL & - & 0.326 & $(4.59)^{* * *}$ & -0.086 & $(-0.29)$ \\
\hline IFRS * BVL & $?$ & -0.049 & $(-0.48)$ & -0.233 & $(-0.59)$ \\
\hline $\mathrm{ARF}$ & - & 0.979 & $(4.1)^{* * *}$ & 0.486 & $(0.81)$ \\
\hline IFRS * ARF & - & -0.849 & $(-2.54) * *$ & -0.533 & $(-0.46)$ \\
\hline GRW & + & -0.492 & $(-2.33)^{* *}$ & -0.017 & $(-0.07)$ \\
\hline IFRS * GRW & $?$ & 1.577 & $(2.84)^{* * *}$ & 0.517 & $(0.93)$ \\
\hline $\mathrm{RD}$ & + & 1.021 & $(0.56)$ & 11.363 & $(3.51)^{* * *}$ \\
\hline IFRS * RD & $?$ & 1.722 & $(0.86)$ & 5.970 & $(1.59)$ \\
\hline \multirow{2}{*}{\multicolumn{2}{|c|}{$\begin{array}{l}\text { Fixed Firm and Year Effects } \\
\qquad R^{2}\end{array}$}} & \multicolumn{2}{|c|}{ Yes } & \multicolumn{2}{|c|}{ Yes } \\
\hline & & \multicolumn{2}{|c|}{0.604} & \multicolumn{2}{|c|}{0.671} \\
\hline \multicolumn{2}{|c|}{ No. of Observations } & & & & \\
\hline
\end{tabular}

Notes: $* * *$, and ${ }^{* * *}$ denote the significance of coefficients at the $10 \%, 5 \%$, and $1 \%$ level, respectively, using a two-tailed test. All the variables are winsorized at the top and bottom $1 \%$. Please see the Appendix A for variable definitions.

Similarly, Panel B of Table 8 presents the results of value relevance tests using the book value of equity as the deflator. Similarly to Panel A of Table 8, the coefficients of $A R F$ (coefficient $=0.979$ and $\mathrm{t}$-statistic $=4.1$ ) and IFRS $\times A R F$ (coefficient $=-0.849$ and $\mathrm{t}$-statistic $=-2.54$ ) in the highly leveraged sample firms are significantly positive and negative, respectively. This suggests that $A R F$ is negatively 
related to equity value after the K-IFRS adoption. In the less-leveraged sample firms, the coefficients of $A R F$ and IFRS $\times A R F$ are not significant. We attribute these results to the role of AR factoring in eliminating credit risk exposure after K-IFRS adoption.

\subsection{Additional Sample}

This study aims to investigate whether the value relevance of AR factoring changes before and after K-IFRS adoption. Thus, the study sample consists of firms that continuously factor AR before and after K-IFRS adoption. However, some firms factor their AR only during particular times. We repeat the tests using an additional sample that includes all firms that factored AR at least once during the sample period in order to observe the overall value relevance of AR factoring.

Table 9 presents the value relevance test results of AR factoring using the additional sample. The coefficient of ARF in the highly leveraged sample firms is marginally significant (coefficient $=-0.386$ and t-statistic $=-1.68$ ), whereas that of IFRS $\times A R F$ is significantly negative (coefficient $=-0.768$ and t-statistic $=-3.18$ ). Consistently with findings in Table 5 , this suggests that AR factoring has negative value relevance after the K-IFRS adoption. In the less-leveraged sample firms, the coefficients on ARF and IFRS $\times A R F$ are significantly positive. The positive significance of the coefficients of $A R F$ is due to the role of AR factoring in reducing credit risk exposure. The significantly positive coefficient on $I F R S \times A R F$ is due to the firms' low-leverage ratio. An increase in leverage ratio positively affects firm value on an under-leverage level from a static trade-off theory standpoint.

Table 9. Value relevance tests of AR factoring using an additional sample.

\begin{tabular}{|c|c|c|c|c|c|}
\hline \multirow[b]{2}{*}{ Variable } & \multirow[b]{2}{*}{ Predicted Sign } & \multicolumn{2}{|c|}{ Highly Leveraged Firms } & \multicolumn{2}{|c|}{ Less-Leveraged Firms } \\
\hline & & Coefficient & (t-Statistics) & Coefficient & (t-Statistics) \\
\hline Intercept & $?$ & 4.467 & $(0.86)$ & 3.894 & $(0.46)$ \\
\hline IFRS & $?$ & 0.051 & $(0.04)$ & -1.795 & $(-0.93)$ \\
\hline NI & + & 2.188 & $(13.78)^{* * *}$ & 1.934 & $(8.13)^{* * *}$ \\
\hline IFRS * NI & $?$ & 1.118 & $(2.62) * * *$ & 0.970 & $(2.87)^{* * *}$ \\
\hline BVA & + & 0.384 & $(10.51)^{* * *}$ & 0.313 & $(5.8)^{* * *}$ \\
\hline IFRS * BVA & $?$ & -0.308 & $(-5.03)^{* * *}$ & -0.099 & $(-1.95) *$ \\
\hline BVL & - & -0.242 & $(-3.48)^{* * *}$ & -0.161 & $(-1.82) *$ \\
\hline IFRS * BVL & $?$ & 0.522 & $(4.76)^{* * *}$ & 0.065 & $(0.55)$ \\
\hline ARF & - & -0.386 & $(-1.68) *$ & 1.130 & $(3.12)^{* * *}$ \\
\hline IFRS * ARF & - & -0.768 & $(-3.18)^{* * *}$ & 3.187 & $(7.61)^{* * *}$ \\
\hline GRW & + & -0.077 & $(-0.08)$ & 0.378 & $(0.17)$ \\
\hline IFRS * GRW & $?$ & 0.557 & $(0.2)$ & -4.688 & $(-0.81)$ \\
\hline RD & + & 4.214 & $(4.31)^{* * *}$ & 3.642 & $(2)^{* *}$ \\
\hline IFRS * RD & $?$ & -0.399 & $(-0.38)$ & 4.654 & $(3.42) * * *$ \\
\hline \multirow{2}{*}{\multicolumn{2}{|c|}{$\begin{array}{l}\text { Fixed Firm and Year Effects } \\
R^{2}\end{array}$}} & \multicolumn{2}{|c|}{ Yes } & \multicolumn{2}{|c|}{ Yes } \\
\hline & & \multicolumn{2}{|c|}{0.883} & \multicolumn{2}{|c|}{0.964} \\
\hline \multicolumn{2}{|c|}{ No. of Observations } & \multicolumn{2}{|c|}{1.998} & \multicolumn{2}{|c|}{1.128} \\
\hline
\end{tabular}

Notes: ${ }^{*} * *$, and ${ }^{* * *}$ denote the significance of coefficients at the $10 \%, 5 \%$, and $1 \%$ level, respectively, using a two-tailed test. All the variables are winsorized at the top and bottom $1 \%$. Please see the Appendix A for variable definitions. All variables except for IFRS and GRW are measured on a per-share basis by deflating by common shares outstanding three months after year-end.

\subsection{A Trend Analysis}

Figure 1 shows the trend of AR. The amount of AR decreased after the pandemic in KSE-50-listed firms, with the exception of financial institutes. The AR was reduced depending on the changes in markets due to the COVID-19 outbreak. However, some firms factored their AR during the pandemic, but others did not. We will repeat the tests using an additional sample that includes post-COVID-19 periods to find out the comparative outcome in a future study. 


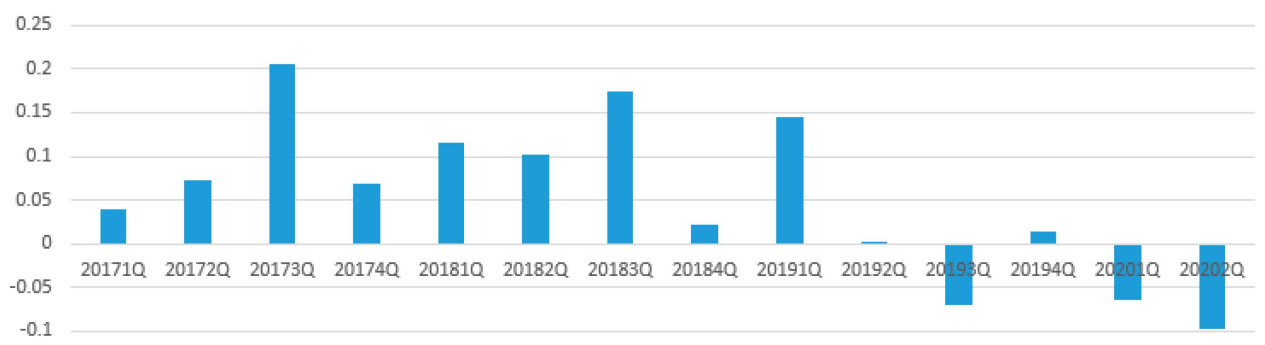

Figure 1. A trend analysis of changes in AR compared to the same quarter last year.

\section{Conclusions}

This study investigates whether recognized AR factoring is more value relevant than disclosed AR factoring. In Korea, most companies factor their AR with recourse. AR factoring with recourse is accounted for as a secured borrowing under K-IFRS, whereas it is accounted for as a sale under K-GAAP. Thus, when a firm factors AR after K-IFRS adoption, it recognizes AR factoring as short-term debt, thereby increasing its leverage ratio. Using 1179 firm-year observations, we find that the valuation coefficients of recognized AR factoring are more significantly negative, whereas those of disclosed AR factoring are not significant. The market value of equity and AR factoring are more negatively correlated in highly leveraged firms than in less-leveraged firms. These results are consistent with the view that the market reacts to recognized information rather than disclosed information when the probability of financial distress is high. This study also shows that highly leveraged firms reduce their AR factoring as a financing tool after K-IFRS adoption.

This study is the first to investigate the effects of IFRS adoption on the relationship between equity market values and the transfer of financial assets. Different treatments of financial asset transfers based on the IFRS and local GAAP have raised concerns. Prior literature mainly discusses asset securitization as an example of financial asset transfer. Jeffrey [37] argues that such a transaction can be treated as an on- or off-balance-sheet item depending on the accounting regime employed. Thus, this inconsistency undermines the purpose of the standards and injures capital markets. Adhikari and Betancourt [38] demonstrate substantial differences in securitization under the US GAAP and IFRS. Generally, market participants are concerned about rigorous standards for financial asset transfers under the IFRS. However, to our knowledge, the IFRS's effects on financial asset transfers using real data have not yet been investigated. Therefore, we believe that the results presented in this study are valuable for standard-setters and researchers.

We also find that highly leveraged firms reduce the use of AR factoring as a financing tool after K-IFRS adoption. These firms may select other financing strategies. For example, they can keep AR to maturity dates, reduce their AR in their business transactions, or sell AR on the condition of a true sale.

The IFRS has been adopted in over 100 countries. There is a vast literature on how IFRS adoption affects, for example, financial reporting quality, capital markets, and auditing. However, we could not find any study that reports how the value relevance of financial asset transfers is different under IFRS and local GAAP. Thus, future research can contribute to the literature by incorporating results from other countries regarding AR factoring and other financial asset transfers. The value relevance of long-term receivables is an interesting issue because they are an important financing source in the financial industry, although we only analyze the value relevance of short-term AR.

From the perspective of sustainability, after the COVID-19 financial shock, the importance of AR factoring is more crucial. Many companies are vulnerable to indulging in temptation to use AR factoring because they want to restore financial status by getting cash in advance after the COVID-19 crisis. In order to improve debt sustainability, companies with high debt would accept to decrease the AR factoring and recover sound debt ratios. Investors are less likely to accept these precarious financial positions, including high debt, if companies introduce mechanisms that will restore financial sustainability once the recovery gets underway. In further studies, we will conduct a comparative study between Korea and other countries. 
Author Contributions: Conceptualization, J.M.P.; methodology, J.M.P.; software, J.M.P.; validation, J.M.P.; formal analysis, J.M.P.; investigation, J.M.P.; resources, J.M.P.; data curation, J.M.P.; writing—original draft preparation, J.M.P.; writing—review and editing, H.Y.L., S.H.P., and I.H.; visualization, J.M.P.; supervision, I.H.; funding acquisition, H.Y.L. All authors have read and agreed to the published version of the manuscript.

Funding: This research was financially supported by Hansung University.

Conflicts of Interest: The authors declare no conflict of interest.

\section{Appendix A}

$\begin{array}{ll}M V E & \text { Price three months after the fiscal year-end multiplied by common shares outstanding } \\ \text { three months after fiscal year-end } \\ \text { BVA } & \text { Net income } \\ B V L & \text { Book value of assets exclusive of recognized AR factoring at fiscal year-end } \\ A R F & \text { Book value of liabilities exclusive of recognized AR factoring at fiscal year-end } \\ I F R S & \text { Short-term accounts receivable factoring amounts at fiscal year-end } \\ G R W & \text { Equal to } 1 \text { if the observation belongs to the post-IFRS adoption period, and } 0 \text { otherwise } \\ R D & \text { Sales growth, equal to the change in the sales divided by sales for the previous year } \\ C S O & \text { Research and development expenses } \\ \triangle A R F & \text { Common shares outstanding three months after the fiscal year-end } \\ \triangle(A R F / A S S E T) & \text { Year-over-year (YOY) changes in AR factoring } \\ & \text { YOY changes in AR factoring divided by total assets, where total assets include } \\ A S S E T & \text { recognized and disclosed AR factoring } \\ \text { Book value of assets at fiscal year-end, which includes recognized AR factoring after } & \text { K-IFRS adoption } \\ F N & \text { AR factoring amount divided by total assets during the post-K-IFRS period; otherwise, } \\ S I Z E & \text { AR factoring amount divided by total assets plus AR factoring amount }\end{array}$

\section{References}

1. Han, K.M. A Study on the Use of International Factoring System-Focusing on SME Export Financing. Unpublished. Ph.D. Thesis, Department of International Trade Sungkyunkwan Unversity, Seoul, Korea, 2009.

2. Kim, J.A.; Choi, J.S. A case study on the accounting for the assignment of account receivable under K-IFRS in export financing. Korean Account. J. 2014, 23, 317-343.

3. Dhaliwal, D.S. Measurement of financial leverage in the presence of unfunded pension obligations. Account. Rev. 1986, 61, 651-661.

4. Imhoff, E.A., Jr.; Lipe, R., Jr.; Wright, D.W., Jr. The effects of recognition versus disclosure on shareholder risk and executive compensation. J. Account. Audit. Financ. 1993, 8, 335-368. [CrossRef]

5. Bratten, B.; Choudhary, P.; Schipper, K. Evidence that market participants assess recognized and disclosed items similarly when reliability is not an issue. Account. Rev. 2013, 88, 1179-1210. [CrossRef]

6. Davis-Friday, P.Y.; Folami, L.B.; Liu, C.-S.; Mittelstaedt, H.F. The value relevance of financial statement recognition vs. disclosure: Evidence from SFAS No. 106. Account. Rev 1999, 74, 403-423. [CrossRef]

7. Ahmed, A.S.; Kilic, E.; Lobo, G.J. Does recognition versus disclosure matter? Evidence from value-relevance of banks' recognized and disclosed derivative financial instruments. Account. Rev. 2006, 81, 567-588. [CrossRef]

8. Michels, J. Disclosure versus recognition: Inferences from subsequent events. J. Account. Res. 2017, 55, 3-34. [CrossRef]

9. Davis-Friday, P.Y.; Liu, C.-S.; Mittelstaedt, H.F. Recognition and disclosure reliability: Evidence from SFAS No. 106. Contemp. Account. Res. 2004, 21, 399-429. [CrossRef]

10. Barth, M.E.; Clinch, G.; Shibano, T. Market effects of recognition and disclosure. J. Account. Res. 2003, 41, 581-609. [CrossRef] 
11. Hirshleifer, D.; Teoh, S.H. Limited attention, information disclosure, and financial reporting. J. Account. Econ. 2003, 36, 337-386. [CrossRef]

12. Dearman, D.T.; Shields, M.D. Avoiding accounting fixation: Determinants of cognitive adaptation to differences in accounting method. Contemp. Account. Res. 2005, 22, 351-384. [CrossRef]

13. Maines, L.A.; McDaniel, L.S. Effects of comprehensive-income characteristics on nonprofessional investors' judgments: The role of financial-statement presentation format. Account. Rev. 2000, 75, 179-207. [CrossRef]

14. Landsman, W.R.; Peasnell, K.V.; Shakespeare, C. Are asset securitizations sales or loans? Account. Rev. 2008, 83, 1251-1272. [CrossRef]

15. Niu, F.F.; Richardson, G.D. Are securitizations in substance sales or secured borrowings? Capital-market evidence. Contemp. Account. Res. 2006, 23, 1105-1133. [CrossRef]

16. Sandback, A. Demystifying Securitization for Unsecured Investors. Available online: https://www.moodys. com/sites/products/AboutMoodysRatingsAttachments/2001700000415918.pdf (accessed on 9 December 2020).

17. Müller, M.A.; Riedl, E.J.; Sellhorn, T. Recognition versus disclosure of fair values. Account. Rev. 2015, 90, 2411-2447. [CrossRef]

18. Cai, J.; Zhang, Z. Leverage change, debt overhang, and stock prices. J. Corp. Financ. 2011, 17, $391-402$. [CrossRef]

19. Opler, T.C.; Titman, S. Financial distress and corporate performance. J. Financ. 1994, 49, 1015-1040. [CrossRef]

20. Dimitrov, V.; Jain, P.C. The value-relevance of changes in financial leverage beyond growth in assets and GAAP earnings. J. Account. Audit. Financ. 2008, 23, 191-222. [CrossRef]

21. Myers, S.C. Capital structure puzzle. J. Financ. 1984, 3, 575-592. [CrossRef]

22. Myers, S.C.; Majluf, N.S. Corporate financing and investment decisions when firms have information that investors do not have. J. Financ. Econ. 1984, 2, 187-221. [CrossRef]

23. Imhoff, E.A., Jr.; Thomas, J.K. Economic consequences of accounting standards: The lease disclosure rule change. J. Account. Econ. 1988, 10, 277-310. [CrossRef]

24. Engel, E.; Erickson, M.; Maydew, E. Debt-equity hybrid securities. J. Account. Res. 1999, 37, $249-274$. [CrossRef]

25. Bens, D.A.; Monahan, S.J. Altering investment decisions to manage financial reporting outcomes: Asset-backed commercial paper conduits and FIN 46. J. Account. Res. 2008, 46, 1017-1055. [CrossRef]

26. Kothari, S.P.; Zimmerman, J.L. Price and return models. J. Account. Econ. 1995, 20, 155-192. [CrossRef]

27. Barth, M.E.; Beaver, W.H.; Landsman, W.R. The relevance of the value relevance literature for financial accounting standard setting: Another view. J. Account. Econ. 2001, 31, 77-104. [CrossRef]

28. Yu, K. Does recognition versus disclosure affect value relevance? Evidence from pension accounting. Account. Rev. 2013, 88, 1095-1127. [CrossRef]

29. Ohlson, J.A. Earnings, book values, and dividends in equity valuation. Contemp. Account. Res. 1995, 11, 661-687. [CrossRef]

30. Feltham, G.A.; Ohlson, J.A. Valuation and clean surplus accounting for operating and financial activities. Contemp. Account. Res. 1995, 11, 689-731. [CrossRef]

31. Barth, M.E.; Beaver, W.H.; Landsman, W.R. The market valuation implications of net periodic pension cost components. J. Account. Econ. 1992, 15, 27-62. [CrossRef]

32. Hann, R.N.; Heflin, F.; Subramanayam, K.R. Fair-value pension accounting. J. Account. Econ. 2007, 44, 328-358. [CrossRef]

33. Mian, S.L.; Smith, C.W., Jr. Accounts receivable management policy: Theory and evidence. J. Financ. 1992, 47, 169-200. [CrossRef]

34. Barth, M.E.; Kallapur, S. The effects of cross-sectional scale differences on regression results in empirical accounting research. Contemp. Account. Res. 1996, 13, 527-567. [CrossRef]

35. Sopranzetti, B.J. The economics of factoring accounts receivable. J. Econ. Bus. 1998, 50, 339-359. [CrossRef]

36. Smith, J.K.; Schnucker, C. An empirical examination of organizational structure: The economics of the factoring decision. J. Corp. Financ. 1994, 1, 119-138. [CrossRef] 
37. Jeffrey, P. International harmonization of accounting standards, and the question of off-Balance sheet treatment. Duke J. Comp. Int. Law 2002, 12, 341.

38. Adhikari, A.; Betancourt, L. Accounting for securitizations: A comparison of SFAS 140 and IASB 39. J. Int. Financ. Manag. Account. 2008, 19, 73-105. [CrossRef]

Publisher's Note: MDPI stays neutral with regard to jurisdictional claims in published maps and institutional affiliations.

(C) 2020 by the authors. Licensee MDPI, Basel, Switzerland. This article is an open access article distributed under the terms and conditions of the Creative Commons Attribution (CC BY) license (http://creativecommons.org/licenses/by/4.0/). 